\title{
Case report: Profound hypotension associated with labetalol therapy in a patient with cerebral aneurysms and subarachnoid hemorrhage
}

\author{
[Une hypotension profonde associée au labétalol chez un patient qui présente des \\ anéprysmes cérébraux et une hémorragie sous-arachnö̈dienne]
}

Sana Jivraj, ${ }^{*}$ C. David Mazer MD, ${ }^{*} \dagger$ Andrew J. Baker MD, ${ }^{*}$ Mabel Choi MD, $\ddagger$ Gregory M.T. Hare MD PhD ${ }^{*} \dagger$

Purpose: Labetalol is an effective antihypertensive medication frequently used to treat systemic hypertension in acute care settings, including the management of hypertension associated with a subarachnoid hemorrhage. We present a case of profound hypotension, refractory to inotropic and vasopressor therapy following an iv infusion of labetalol.

Clinical features: Initiation of an iv labetalol infusion resulted in good blood pressure control in a patient suffering from a Fisher grade 3 subarachnoid hemorrhage with an initial Glascow coma scale of 14/15 and mild hydrocephalus. Progressive deterioration of neurological symptoms and evidence of worsening hydrocephalus preceded the sudden development of profound hypotension $(60 / 35 \mathrm{mmHg})$ and bradycardia with a minimum heart rate of 40 beats $\cdot \mathrm{min}^{-1}$. Initial resuscitative efforts included administration of intravascular fluid, hypertonic saline, atropine, adrenalin (more than $10 \mathrm{mg}$ in divided doses) and noradrenalin. These measures restored the blood pressure to $80 / 45$ with a HR of 98 beats $\cdot \mathrm{min}^{-1}$. Intraoperative placement of an intraventricular drain released cerebrospinal fluid under pressure with an initial intracranial pressure of $15 \mathrm{~cm} \mathrm{H}_{2} \mathrm{O}$. A combination of adrenalin, noradrenalin, dopamine and vasopressin infusions were required to restore the blood pressure to $130 / 65 \mathrm{mmHg}$ after an additional two hours. All inotropic and vasopressor support was weaned off after the 14th hr (about two drug half-lives). The patient was awake and responsive the following day, with no obvious neurological consequences. No evidence of neurological injury, drug administration error or myocardial dysfunction was documented.

Conclusion: The episode of profound hypotension which occurred after initiating a labetolol infusion required maximal combined vasopressor therapy to restore the blood pressure suggesting that this patient demonstrated an extreme sensitivity to labetalol. Combination therapy with adrenergic and nonadrenergic agonists may be required for optimal treatment of profound hypotension associated with labetalol-induced vasoplegia.

Objectif: Le labétalol est un antihypertenseur efficace souvent utilisé contre l'hypertension généralisée dans le cadre de soins actifs, y compris le traitement de l'hypertension associée à une hémorragie sous-arachnoïdienne. Nous présentons un cas d'hypotension profonde, réfractaire aux inotropes et aux vasopresseurs à la suite d'une perfusion iv de labétalol.

Éléments cliniques : L'administration d'une perfusion iv de labétalol a bien contrôlé la tension artérielle chez un patient souffrant d'une hémorragie sous-arachnoïdienne de grade 3 de Fisher accompagnée d'un coma initial de 14/I5 à l'échelle de Glasgow et d'une légère hydrocéphalie. La détérioration neurologique progressive et l'aggravation évidente de l'hydrocéphalie ont précédé le développement soudain d'une profonde hypotension $(60 / 35 \mathrm{mmHg})$ et de bradycardie avec une fréquence cardiaque (FC) minimale de 40 battements $\cdot \mathrm{min}^{-1}$. La réanimation a d'abord consisté en l'administration intravasculaire de liquide, de solution saline hypertonique, d'atropine, d'adrénaline (plus de $10 \mathrm{mg}$ en doses divisées) et de noradrénaline. La tension artérielle a été restaurée à 80/45 avec une FC de 98 battements $\cdot \mathrm{min}^{-1}$. La mise en place peropératoire d'un drain intraventriculaire a libéré du liquide céphalorachidien sous pression pour une pression intracrânienne initiale de 15 $\mathrm{Cm} \mathrm{H}_{2} \mathrm{O}$. Des perfusions combinées d'adrénaline, de noradrénaline, de dopamine et de vasopressine ont permis de restaurer la tension artérielle à $130 / 65 \mathrm{mmHg}$, deux heures plus tard. Toute assistance inotropique et vasopressive a été retirée après la $14^{\mathrm{e}} \mathrm{h}$ (environ

From the Departments of Anesthesia, ${ }^{*}$ Cara Phelan Centre for Trauma Research, St. Michael's Hospital, University of Toronto, Department of Physiology, $\dagger$ University of Toronto, and the Department of Anesthesia, $\ddagger$ Sunnybrook and Women’s Health Sciences Centre, Toronto, Ontario, Canada.

Address correspondence to: Dr. Gregory M.T. Hare, Departments of Anesthesia and Physiology, University of Toronto, St. Michael's

Hospital, 30 Bond Street, Toronto, Ontario M5B 1W8, Canada. Phone: 416-864-5825; Fax: 416-864-6014;

E-mail: hareg@smh.toronto.on.ca

Accepted for publication January 3, 2006.

Revision accepted February 2, 2006.

Competing interests: None declared. 
deux demi-vies du médicament). Le patient était éveillé et apte à réagir le jour suivant, sans séquelles neurologiques apparentes. Aucune évidence de lésion neurologique, d'erreur d'administration de médicament ou de dysfonction myocardique n'ont été documentées.

Conclusion: L'épisode d'hypotension profonde survenue après l'administration d'une perfusion de labétalol a nécessité un traitement vasopresseur maximal combiné pour restaurer la tension artérielle, ce qui laisse croire que ce patient a démontré une extrême sensibilité au labétalol. La combinaison d'agonistes adrénergiques et non adrénergiques peut être nécessaire comme traitement optimal de l'hypotension profonde associée à la vasoplégie induite par le labétalol.

I NTRAVENOUS labetalol is a commonly used antihypertensive agent in acute care settings, including the emergency department, operating rooms and intensive care units. ${ }^{1-3}$ The drug is often used clinically to treat systemic hypertension in patients who have suffered a subarachnoid hemorrhage secondary to a ruptured cerebral aneurysm. Labetalol consists of a racemic mixture of four isomers. The combined effect on adrenergic receptors include $\beta_{1}$ and $\alpha_{1}$ adrenergic blockade and some degree of $\beta_{2}$ adrenergic stimulation. ${ }^{4,5}$ Labetalol's $\beta_{2}$ agonist activity is attributed to dilevalol which makes up about $25 \%$ of the racemic drug mixture. ${ }^{6}$ The relative binding affinity for $\beta$ receptors is about four- to tenfold greater than its affinity for $\alpha$ receptors. ${ }^{4}$ These receptor mediated effects lead to a significant reduction in cardiac output, heart rate (HR) and systemic vascular resistance. Comparable drug blood levels can be achieved after about one hour of $i v$ or oral administration. ${ }^{7}$ The serum half-life of labetalol is six to eight hours after oral administration and about five to six hours after iv administration. When administered orally or parenterally, labetalol is a potent and effective antihypertensive medication. Despite its generally predictable antihypertensive effects, case reports of significant hypotension following labetalol administration suggest that some patients may be particularly sensitive to its antihypertensive action. ${ }^{1,8-11}$ Under such conditions, labetalol's relatively long elimination half-life (five to eight hours) renders it unfavourable if rapid reversibility is required. We report a case of profound hypotension and bradycardia in a neurosurgical patient in which a labetalol infusion was used to control hypertension secondary to a subarachnoid hemorrhage.

\section{Case report}

Consent for use of personal information was obtained in accordance with the institutional guidelines at St. Michael's Hospital. A 64-yr-old $72 \mathrm{~kg}$ woman was admitted to the neurosurgical intensive care unit (NICU) with a Fisher grade 3 subarachnoid hemorrhage. Her past medical history was remarkable for migraine headaches, hemicolectomy for colonic cancer and a positive family history for cerebral aneurysm. Her presenting symptoms included headache, nausea and mild disorientation to place and time with a Glascow coma scale of $14 / 15$. She was able to move all four limbs and obeyed commands with no focal neurological deficits. The blood pressure on admission was $190 / 110 \mathrm{mmHg}$, with a HR of 60 beats. $\mathrm{min}^{-1}$. The patient's hypertension was initially treated with a labetalol infusion at a rate of $120 \mathrm{mg} \cdot \mathrm{hr}^{-1}$. No bolus loading dose was given. Oral nimodipine had not yet been administered. Over the first two to three hours, the target systolic blood pressure of $140-160 \mathrm{mmHg}$ was achieved. A cerebral angiogram identified aneurysms at multiple locations, including the right anterior choroidal and left ophthalmic arteries.

After three hours, the patient became more somnolent and stopped verbalizing. An urgent computed tomography scan was performed which demonstrated moderate worsening of hydrocephalus and cerebral edema. Shortly after returning to the NICU, the patient's blood pressure dropped to $60 / 35 \mathrm{mmHg}$ with a mean arterial pressure (MAP) of $48 \mathrm{mmHg}$ and a HR of 40 beats. $\mathrm{min}^{-1}$. The labetalol infusion was immediately discontinued and resuscitation was initiated with a working diagnosis of raised intracranial pressure (ICP) and brain stem compression resulting in compromised cardiovascular function. Initial resuscitative therapy included a bolus of hypertonic saline $(200 \mathrm{~mL} 3 \%$ solution $i v)$, pentastarch $(500 \mathrm{~mL}$ $i v)$, atropine $(0.5 \mathrm{mg} i v)$, and a dopamine infusion titrated to $20 \mathrm{ug} \cdot \mathrm{kg}^{-1} \cdot \mathrm{min}^{-1}$. The patient's trachea was intubated and preparations were made for transfer to the operating room for emergent placement of an intraventricular drain. At this time, the systolic blood pressure remained below $70 \mathrm{mmHg}$. Pulse oximetry demonstrated a saturation of $100 \%$. Adrenaline was administered in rapidly escalating boluses from 5 to $200 \mu \mathrm{g} i \mathrm{v}$. This combination increased the patient's blood pressure to $80 / 45 \mathrm{mmHg}$ with a MAP of $58 \mathrm{mmHg}$ and a HR of 98 beats. $\mathrm{min}^{-1}$. A working diagnosis of cardiovascular collapse secondary to raised ICP and hydrocephalus was maintained, and the patient was taken to the operating room for insertion of an intraventricular drain. During transfer, the patient was hyperventilated (100\% oxygen) 
and repeated boluses of adrenalin (100-200 $\mu \mathrm{g}$ ) were given to maintain the systolic blood pressure in the range of $70-80 \mathrm{mmHg}$ with a HR near 100 beats. $\mathrm{min}^{-1}$. More than $10 \mathrm{mg}$ of adrenalin had been administered in divided doses to maintain the systolic blood pressure above $70 \mathrm{mmHg}$ in the NICU, and en route to the operating room. In the operating room, adrenalin and noradrenalin infusions were established each at a rate of $0.2 \mu \mathrm{g} \cdot \mathrm{kg}^{-1} \cdot \mathrm{min}^{-1}$. Additional adrenalin boluses $(100 \mu \mathrm{g})$ were also required to maintain an adequate blood pressure. Midazolam ( $2 \mathrm{mg} i v)$ and rocuronium $(50 \mathrm{mg} i v)$ and calcium chloride (l g iv) were administered. The surgical site was infiltrated with local anesthetic and a ventriculostomy was performed under sterile conditions. After successful insertion of the ventricular drain, cerebrospinal fluid was released under pressure. Following cerebral spinal fluid decompression, the initial ICP was recorded at $15 \mathrm{~cm} \mathrm{H}_{2} \mathrm{O}$. Blood gas values at this point were: $\mathrm{pH}$ $=7.47, \mathrm{P}_{\mathrm{a}} \mathrm{CO}_{2}=24 \mathrm{mmHg}$, and $\mathrm{P}_{\mathrm{a}} \mathrm{O}_{2}=552 \mathrm{mmHg}$. A Swan-Ganz catheter was inserted and utilized to measure the cardiac index $\left(3.8 \mathrm{~L} \cdot \mathrm{min}^{-1} \cdot \mathrm{m}^{-2}\right)$, pulmonary artery pressure $(30 / 18 \mathrm{mmHg})$ and pulmonary artery wedge pressure $(20 \mathrm{mmHg})$.

Upon transfer to the NICU, two boluses of vasopressin $(1 \mathrm{u} i v)$ were administered. This resulted in a transient increase in MAP. A vasopressin infusion was initiated at $2.4 \mathrm{u} \cdot \mathrm{hr}^{-1}$. At the time of initiating the vasopressin infusion the blood pressure was $100 / 55$ $\mathrm{mmHg}$ with a MAP of $70 \mathrm{mmHg}$, and $\mathrm{HR}=115$ beats. $\mathrm{min}^{-1}$. After one hour, the MAP was $87 \mathrm{mmHg}$ and the HR was 100 beats. $\mathrm{min}^{-1}$. After two hours, MAP was $92 \mathrm{mmHg}$ and the HR was 83 beats $\mathrm{min}^{-1}$. Over the next five hours, all adrenergic drug infusions were weaned. The vasopressin infusion was maintained for four more hours (Figure). By the 14th hr following the initial hypotensive event, the MAP was 103 $\mathrm{mmHg}$ at a HR of 67 beats. $\mathrm{min}^{-1}$ without any vasopressor or inotropic support (Figure). The patient's neurological status improved progressively over $18 \mathrm{hr}$. At this point, the patient was obeying commands with a Glascow coma scale of $11 \mathrm{~T} / 15$. Nimodipine therapy was initiated about $12 \mathrm{hr}$ after recovery of the blood pressure. The patient's trachea was extubated after 24 hr with the patient's Glascow coma scale of 15/15. No clinical or radiographic evidence of cerebral injury secondary to the hypotensive event was observed.

Subsequent laboratory tests revealed no impairment of renal or hepatic function. Assessment of the patient's cardiovascular status included an electrocardiogram demonstrating non-specific ST and T wave abnormalities, a mild increase in troponin to 0.15 $\mu \mathrm{g} \cdot \mathrm{L}^{-1}$, and an echocardiogram demonstrating normal

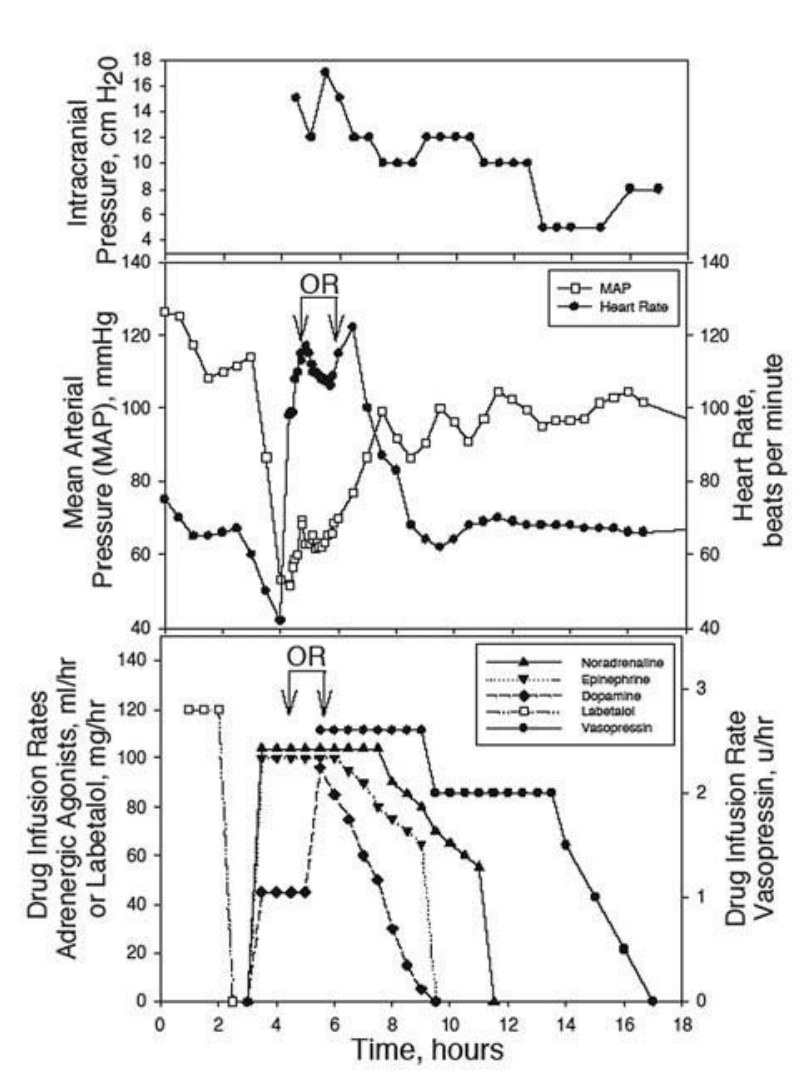

FIGURE Top panel: intracranial pressure was initially 15 $\mathrm{cm} \mathrm{H}_{2} \mathrm{O}$ in the operating room, and remained relatively stable throughout. Middle panel: changes in blood pressure and heart rate before, during and after placement of the intraventricular drain in the operating room. Note that the heart rate increased rapidly in response to adrenergic medications, whereas blood pressure remained low. Addition of vasopressin was associated with a gradual but significant increase in mean arterial blood pressure. Bottom panel: the timing of labetalol, vasopressor and inotropic administration is identified. As the mean arterial pressure was normalized, all antihypertensive medications were discontinued.

ventricular function without any specific wall motion abnormalities. The cardiologist's assessment suggested that the slight increase in troponin was likely due to subendocardial ischemia secondary to hypotension and/or to the pharmacological effects of large dose catecholamine administration.

\section{Discussion}

Intravenous labetalol is frequently used in the treatment of hypertension in a number of clinical settings including subarachnoid hemorrhage. ${ }^{2}$ Clinical reports and the product monogram recommend infusion 
rates between 0.5 to $2 \mathrm{mg} \cdot \mathrm{min}^{-1}{ }^{1,12,13}$ A blood pressure response can be seen as early as five to $30 \mathrm{~min}$ following an initial $i v$ bolus injection of $20-80 \mathrm{mg}$. However, frequent boluses of up $300 \mathrm{mg}$ cumulatively are sometimes required to achieve the desired blood pressure effect. ${ }^{13-15}$ Variability in the blood pressure response to labetalol has been observed. In one clinical study, the response time varied from 15 to $70 \mathrm{~min}$ with a duration of effect from two to $24 \mathrm{hr}$ following iv administration of $300 \mathrm{mg}$ of labetalol. ${ }^{16}$ In two of 17 patients, no blood pressure response was observed in response to labetalol $300 \mathrm{mg} i \mathrm{v}^{16}$ In other studies, an initial bolus of $300 \mathrm{mg}$ did not adequately control systemic blood pressure in some patients. ${ }^{12,15}$ Infusion doses of up to $2-3 \mathrm{mg} \cdot \mathrm{min}^{-1}$ have been used for up to 14 days to control hypertension. ${ }^{17}$ These reports emphasize that there is significant variability in the response to $i v$ labetalol. The dose of labetalol used in the current patient falls well within these recommended parameters. A total of $360 \mathrm{mg}$ of labetalol was infused slowly over three hours to prove adequate blood pressure control. However, significant hypotension and bradycardia ensued.

The severe hypotensive response observed in this report occurred about three hours after the infusion had begun. This delayed response may have been due to slow accumulation of serum drug levels in the absence of a loading dose. However, labetalol's onset time can be highly variable in hypertensive patients. Similarly, the time to severe hypotensive complications associated with labetalol therapy is also variable. In several reports, a pronounced hypotensive response has been observed close to the time of drug administration. ${ }^{9,10}$ However, in another report, blood pressure decreased about two hours following a $600 \mathrm{mg}$ oral dose in a patient who had received furosemide, clonidine and labetalol (400 mg bid). ${ }^{8}$ The longest delay in a reported hypotensive event associated with labetalol occurred in a patient on cardiopulmonary bypass, three hours following discontinuation of an infusion of the drug. ${ }^{11}$ Therefore, the three-hour delay in onset of severe hypotension is consistent with the pharmacokinetic and clinical profile of labetalol.

Severe hypotension associated with labetalol therapy has occurred with co-administration of other antihypertensive or vasoactive medications. ${ }^{8-11}$ Commonly, the hypotension was not responsive to adrenergic agonists. ${ }^{8-11}$ In one case, glucagon was co-administered with adrenergic medications to restore blood pressure following labetalol-induced hypotension. ${ }^{8}$ The current case demonstrates that hypotension can occur following labetalol administration in the absence of additional vasoactive medication. A combination of adrenergic and non-adrenergic inotropes and vasopressors may be required to restore blood pressure. Presumably, vasopressin contributed to restoration of blood pressure by acting at the $V_{1}$ receptor on vascular smooth muscle. Support for this argument is provided by another case report in which vasopressin restored the blood pressure of a patient experiencing profound hypotension secondary to $\alpha$ adrenergic blockade following phenoxybenzamine administration. ${ }^{18}$ The refractory nature of labetalol-induced hypotension is emphasized by the finding that, in two cases, labetalol-induced hypotension led to cardiac arrest and death. ${ }^{9,10}$ Thus, severe cardiovascular morbidity and mortality has been associated with labetalol therapy, despite frequent statements in clinical reports that the drug can be used safely without significant adverse side effects. ${ }^{1,14,15}$ In the current case, the combination of adrenergic agonists and vasopressin appeared to be the most effective drug combination required to restore systemic vascular resistance and maintain adequate cardiac output. Therefore, such combined drug therapy may provide the best means for treating refractory hypotension secondary to labetalol-induced hypotension.

The differential diagnoses for the episode of hypotension observed in the current case includes: 1) profound neurological compromise with raised ICP and compression on the cardiovascular centres within the brain stem; 2) cardiogenic shock; 3) incorrect drug dose administration; 4) anaphylactoid or anaphylactic reaction; and 5) atypical vascular sensitivity to labetalol.

In an attempt to rule out a neurological cause in the setting of increased ICP and subarachnoid hemorrhage, standard measures were initiated to reduce the ICP including administration of hypertonic saline and hyperventilation. The patient was then taken to the operating room for insertion of an intraventricular drain. At surgery, the cerebral spinal fluid was not under high pressure, possibly due to the effectiveness of earlier administered therapy for raised ICP. The immediate post-decompression ICP measurement was not elevated $\left(15 \mathrm{~cm} \mathrm{H}_{2} \mathrm{O}\right)$. This would suggest that measures to control the raised ICP were effective and that any brain stem compression was not maintained for a prolonged period. Although brain stem compression can cause transiently reduced MAP and HR, removal of this compression usually results in a rapid resolution of the hypotension. ${ }^{19}$ Furthermore, the vascular response to $\alpha$ agonists is not usually impaired under these conditions. In severe cases of raised ICP, cardiovascular centres may be compromised, leading to hypotension; however, such hypotension usually 
responds to adrenergic stimulation and/or vasopressin. The lack of a rapid response to these drugs in the current case argues in favour of labetalol-induced vasoplegia. The prolonged period of refractory hypotension and relatively low initial ICP argues against brain stem compression as the primary cause of hypotension.

No evidence of a primary cardiac event was observed. The initial post-resuscitation increase in HR was likely due to the effect of co-administration of atropine and adrenalin. Intraoperatively, the cardiac index was measured at $3.8 \mathrm{~L} \cdot \mathrm{min}^{-1} \cdot \mathrm{m}^{-2}$. This suggests that profound cardiac dysfunction was not likely responsible for the observed hypotension. However, the inability to rapidly restore blood pressure suggests that the cardiac response was insufficient in the context of labetalolinduced vasoplegia. Due to its strong effect on $\beta_{1}$ adrenergic receptors, a residual inhibition of cardiac contractility may have also contributed. The lack of echocardiographic evidence of myocardial injury also argues against a cardiogenic cause for hypotension.

The possibility that an error in drug administration was responsible for the observed hypotension also seems unlikely for the following reasons: firstly, the duration of the requirement for vasopressor and inotropic agents was relatively short, approximately two drug half-lives. The plasma half-life for $i v$ labetalol is about $5.5 \mathrm{hr}$, and blood pressure may not return to pre-treatment levels for an average of 16 to 18 hr following iv administration. ${ }^{12,16}$ If an overdose of labetalol were administered, a longer period of pharmacological support would be needed to restore the blood pressure; secondly, the increase in HR over the first two to three hours of adrenergic drug administration suggests that there was some degree of $\beta_{1}$ stimulation prior to full recovery of blood pressure. Since labetalol has a much higher affinity for the beta receptor $(7: 1)$, a drug overdose would be expected to have a refractory bradycardic effect. ${ }^{7}$ The observed increase in HR would suggest that adrenergic stimulation of $\beta_{1}$ receptors was partially intact. This response would not be expected in the presence of a large increase in drug concentration; finally, administration of vasopressin, in addition to adrenergic agonists, appeared to steadily restore blood pressure within the first two hours of its administration. Therefore, an inadvertent drug overdose was unlikely to have been responsible for the episode of hypotension observed in this patient. Furthermore, there were no clinical signs of an anaphylactoid or anaphylactic event which should have responded more rapidly to adrenalin therapy.

The authors favor the explanation that this patient may have exhibited an extreme sensitivity to the $\alpha_{1}$ blocking and/or $\beta_{2}$ agonist effect of labetalol. The presence of profound hypotension despite high doses of noradrenalin and vasopressin suggests an inability of the vasculature to respond to these pharmacological agonists. This vasoplegia seemed to resolve within about two half-lives of the drug, suggesting that the patient had a significant sensitivity to labetalol. The lack of response to high doses of adrenergic vasopressors argues in favour of a non-responsive vasculature. The etiology of this patient's sensitivity to labetalol could be secondary to genetic variability. Our understanding of the role of genetics with respect to heterogenous responses to antihypertensive drugs has expanded recently. ${ }^{20}$ Genetic variations in the $\alpha$ and $\beta$ adrenergic receptor can have a profound effect on the physiologic and pharmacologic regulation of blood pressure in humans. ${ }^{21-23}$ Despite labetalol's relative safe therapeutic index, several case reports suggest that profound hypotension, cardiac arrest and death can occur with a relatively small dose of labetalol. These events often occur when labetalol is used in combination with additional vasoactive drugs. ${ }^{1,8-11}$ In the current case, refractory hypotension was observed following administration of a clinically recommended drug dose, in the absence of other anti-hypertensive medications. Therefore, enhanced sensitivity of the $\alpha_{1}$ and/or $\beta_{2}$ receptors may have contributed to the observed effect. The $\alpha_{1}$ adrenergic receptor may be the most important mechanism because labetalol induced hypotension has been reported to be unresponsive to phenylephrine. ${ }^{11}$

In conclusion, labetalol is an effective drug for treating hypertension in a number of clinical settings. However, its dose should be titrated carefully and minimal effective infusion doses should be utilized. In the event of profound or unexpected hypotension, a combination of adrenergic and non-adrenergic inotropic and vasopressor medications may provide the best means of resuscitating the patient and restoring systemic blood pressure.

\section{References}

1 Lebel M, Langlois S, Bellean LJ, Grose JH. Labetalol infusion in hypertensive emergencies. Clin Pharmacol Ther 1985 ; 37: 615-8.

2 Panagos PD, Jauch EC, Broderick JP. Intracerebral hemorrhage. Emerg Med Clin North Am 2002; 20: 631-55.

3 Kross $R A$, Ferri E, Leung D, et al. A comparative study between a calcium channel blocker (nicardipine) and a combined alpha-beta-blocker (labetalol) for the control of emergence hypertension during craniotomy for tumor surgery. Anesth Analg 2000; 91: 904-9.

4 Kirsten R, Nelson K, Kirsten D, Heintz B. Clinical 
pharmacokinetics of vasodilators. Part II. Clin

Pharmacokinet 1998; 35: 9-36.

5 Baum T, Watkins RW, Sybertz EJ, et al. Antihypertensive and hemodynamic actions of $\mathrm{SCH}$ 19927, the R,R-isomer and labetalol. J Pharmacol Exp Ther 1981; 218: 444-52.

6 Louis WJ, Drummer OH, Tung LH. Actions of dilevalol on adrenoceptors. J Cardiovasc Pharmacol 1988; 11(Suppl 2): S5-11.

7 Louis WJ, Christophidis N, Brignell M, Vijayasekaran V, McNeil J, Vajda FJ. Labetalol: bioavailability, drug plasma levels, plasma renin and catecholamines in acute and chronic treatment of resistant hypertension. Aust N Z J Med 1978; 8: 602-9.

8 Kollef $M H$. Labetalol overdose successfully treated with amrinone and alpha-adrenergic receptor agonists. Chest 1994; 105: 626-7.

9 Tung A, Sweitzer B, Cutter T. Cardiac arrest after labetalol and metoclopramide administration in a patient with scleroderma. Anesth Analg 2002; 95: 1667-8.

10 Schier JG, Howland MA, Hoffman RS, Nelson LS. Fatality from administration of labetalol and crushed extended-release nifedipine. Ann Pharmacother 2003; 37: 1420-3.

11 Durant PA, Joucken K. Bronchospasm and hypotension during cardiopulmonary bypass after preoperative cimetidine and labetalol therapy. Br J Anaesth 1984; 56: 917-20.

12 Wright JT Jr, Wilson DJ, Goodman RP, Minisi AJ. Labetalol by continuous intravenous infusion in severe hypertension. J Clin Hypertens 1986; 2: 39-43.

13 Gonzalez DG, Ram VS. New approaches for the treatment of hypertensive urgencies and emergencies. Chest 1988; 93: 193-5.

14 Wilson DJ, Wallin JD, Vlachakis ND, et al. Intravenous labetalol in the treatment of severe hypertension and hypertensive emergencies. Am J Med 1983; 75: 95102.

15 Papademetriou V, Notargiacomo AV, Khatri IM, Freis $E D$. Treatment of severe hypertension with intravenous labetalol. Clin Pharmacol Ther 1982; 32: 431-5.

16 Cressman MD, Vidt DG, Gifford RW Jr, Moore WS, Wilson DJ. Intravenous labetalol in the management of severe hypertension and hypertensive emergencies. Am Heart J 1984; 107: 980-5.

17 Goldsmith TL, Barker DE, Strodel WE. Prolonged labetalol infusion for management of severe hypertension and tachycardia in a critically ill trauma patient. DICP 1990; 24: 235-8.

18 O'Blenes SB, Roy N, Konstantinov I, Bobn D, Van Arsdell GS. Vasopressin reversal of phenoxybenzamineinduced hypotension after the Norwood procedure. J Thorac Cardiovasc Surg 2002; 123: 1012-3.
19 Endo T, Sato K, Takabashi T, Kato M. Acute hypotension and bradycardia by medulla oblongata compression in spinal surgery. J Neurosurg Anesthesiol 2001; 13: 310-3.

20 Bamshad M. Genetic influences on health. Does race matter? JAMA 2005; 294: 937-46.

21 Buzas B, Belfer I, Hipp H, et al. Haplotype block and superblock structures of the alphal-adrenergic receptor genes reveal echoes from the chromosomal past. Mol Genet Genomics 2004; 272: 519-29.

22 Dishy V, Landau R, Sofowora GG, et al. Beta 2 -adrenoceptor Thrl64Ile polymorphism is associated with markedly decreased vasodilator and increased vasoconstrictor sensitivity in vivo. Pharmacogenetics 2004; 14: 517-22.

23 Nickander KK, Carlson PJ, Urrutia RA, Camilleri M, Low PA. A screen of candidate genes and influence of beta $_{2}$-adrenergic receptor genotypes in postural tachycardia syndrome. Auton Neurosci 2005; 120: 97-103. 